\title{
ע Covid-19-pandemian alkuvaihe ja Husin henkilöstön psyykkinen kuormitus
}

COVID-19-pandemian aikana terveydenhuollon kantokyky on noussut yhdeksi keskeisistä huolenaiheista. Pandemian alkuvaiheessa valmiutta kohotettiin ja työtehtävät muuttuivat, joka vaikutti sairaaloiden koko henkilöstön arkeen. Ensimmäiset kansainväliset tulokset terveydenhuoltohenkilöstön hyvinvoinnista COVID-19-pandemian aikana kuvasivat monimuotoista psyykkistä kuormittuneisuutta. Suomessa valtaosa COVID-19-tartunnoista on ollut HUS Helsingin yliopistollisen sairaalan alueella. Kuvaamme kesäkuussa 2020 käynnistetyn HUS-henkilöstön hyvinvointia seuraavan kohorttitutkimuksen keskeisiä alkuvaiheen tuloksia siihen osallistuneiden 4804 henkilön (19\% HUSin henkilöstöstä) vastausten perusteella suhteessa työn muutoksiin. Tavoitteena oli selvittää pandemian aiheuttamien työn muutosten yhteyksiä koettuun psyykkiseen kuormittuneisuuteen strukturoidun Mental Health Index -5 kyselylomakkeen avulla. Lisäksi sähköisessä kyselyssä kysyttiin muiden strukturoitujen lomakkeiden ja avoimien kysymysten kautta uniongelmista, masennus- ja ahdistuneisuusoireista, poikkeuksellisesta psyykkisestä pandemiaan liittyvästä kuormituksesta, sekä koettua psyykkisen tuen tarvetta ja tuen saamista organisaation kautta. Kesäkuussa 2020 suurin kuormittuneisuus vaikutti olevan yksiköissä, joissa COVID-19-potilaita hoidettiïn pitkäkestoisesti tai tehtiin potilaiden diagnostiikkaa sekä työntekijöillä, joiden työ oli muuttunut melko paljon, mutta eniten ja vähiten COVID - 19 potilaita hoitavissa yksiköissä itseilmoitettu psyykkinen kuormittuneisuus oli vähäisempää. Viidesosa psyykkisen tuen tarvetta kokeneista oli ollut tuen piirissä HUS organisaation tukitoimien kautta. Ahdistuneisuus-, masennus- ja uniongelmiin on tärkeä kiinnittää huomiota henkilöstön työ- ja toimintakyvyn varmistamiseksi työtehtävien nopeasti muuttuessa.

ASIASANAT: Psyykkinen kuormitus, COVID-19 pandemia, sairaalahenkilöstö, uni, mieliala, psyykkiset traumat

HENNA HARAVUORI, JAANA SUVISAARI, ANU PELLIKKA, KRISTIINA JUNTTILA, TONI HAAPA*, TANJA LAUKKALA* (*jaettu viimeinen kirjoittajuus)

\section{YDINASIAT}

- COVID-19-pandemiaan liittyi HUSin henkilöstöllä väestöön keskimäärin verrattuna lisääntynyttä psyykkistä kuormitusta strukturoidulla oirekyselyllä arvioituna kesäkuussa 2020 käynnistetyn kyselytutkimuksen perusteella.

- Osin pandemiatyöhön siirtyminen vaikutti kuormittavammalta kuin jatkuva pandemiapotilaiden hoito COVID - 19 pandemian alkuvaiheessa sairaalahenkilöstöllä, mikä saattaa liittyä työn muutoksiin.

- Erityisesti hoitohenkilöstö kuormittui merkittävästi muihin ammattiryhmiin verrattuna.
JOHDANTO

COVID-19-pandemian alkuvaiheessa hallitus totesi 13.3.2020 poikkeusolot, otti valmiuslain käyttöön ja teki useita rajoittamistoimenpiteitä koskevia linjauksia. 15.6.2020 valtioneuvosto tiedotti niiden päättymisestä. Kesällä 2020 koronatilanne helpottui, mutta paheni jälleen syksyllä (ns. toinen aalto) ja alkuvuodesta 2021 (ns. kolmas aalto). Pandemian alkuvaiheessa HUS siirtyi täysvalmiuteen 19.3.2020 ja uudelleen 23.11.2020 suuronnettomuusohjeistuksen mukaan ja siten toiminta Uudenmaan alueella eteni tehokkaana pandemiasairastavuuden muuttuessa. Alueella 
on vuoden 2020 ajan kannettu päävastuu COVID-19-potilaiden hoidosta, vaikka yksittäisiä potilaita on siirretty tehohoitoon myös muualle Suomeen. Useissa kansainvälisissä vertailuissa Suomen on arvioitu selviytyneen keskeisissä pandemian rajoitustoimissa hyvin $(1,2)$. Suomessa COVID-19-pandemiaan kuolleista valtaosa on ikääntyneitä, vaikka tehohoitotarve on ajoittain lisääntynyt myös nuoremmissa ikäryhmissä.

COVID-19-pandemian alkuvaiheessa julkaistiin ensimmäiset raportit sen aiheuttamasta kuormituksesta terveydenhuoltohenkilöstölle $(3,4)$. Hyvän psykososiaalisen tuen yleisiin periaatteisiin kuuluu psyykkisen hyvinvoinnin seuranta ja jaksamista voidaan tukea monin eri tavoin (5-8). HUSin henkilöstölle on tehty erillinen pandemiaajan psyykkisen tuen tukiportaali loppukeväästä 2020, samaan aikaan nyt kuvatun kohorttitutkimuksen käynnistyessä (6). Se täydentää osaltaan muita käytettävissä olevia terveyspalveluita, kuten HUSin työterveyshuoltoa, jonka kapasiteettia COVID-19-pandemia myös rajoittaa mm. koska osa sen henkilöstöstä tarvitaan pandemiaan liittyviin tehtäviin, kuten rokotuksiin.

COVID-19 pandemian aikana terveydenhuoltohenkilöstö on raportoinut psyykkistä kuormittuneisuutta ahdistuneisuus-, masennus- ja uniongelmin (3-12), joihin on tärkeä kiinnittää huomiota sairaalahenkilöstön työ- ja toimintakyvyn varmistamiseksi erityisesti pitkittyvässä pandemiatilanteessa $(13,14)$. Suomessa valtaosa COVID-19-tartunnoista oli pandemian alkuvaiheessa Helsingin ja Uudenmaan alueella ja pandemia levisi koko maahan vuoden 2020 aikana.

Kuvaamme tässä tutkimusartikkelissa kesäkuussa 2020 käynnistetyn HUSin henkilöstön hyvinvointia seuraavan 18 kuukauden kohorttitutkimuksen (15) alkuvaiheen tuloksia psyykkisten kuormitusoireiden, työtehtävien muutosten ja psyykkisen tuen itseilmoitetun tarpeen ja saamisen osalta. Tutkimus toteutetaan toistuvien sähköpostitse lähetettävien kyselyjen kautta. Kohorttitutkimus seuraa, onko pandemian aikana ja sen jälkeen ensilinjassa COVID-19-potilaita hoitanut tai hoitoon osallistunut HUSin sairaalahenkilöstö muuta henkilöstöä kuormittuneempaa $(15,16)$.

\section{AINEISTO JA MENETELMÄT}

Seurantatutkimuksen kohteena on HUS Helsingin yliopistollisen sairaalan koko henkilöstö. Ke- säkuun 2020 alussa HUSissa oli yhteensä 25505 aktiivisessa työ- tai virkasuhteessa olevaa työntekijää (sisältäen vakituiset ja määräaikaiset työntekijät). Tutkimukseen kutsuttiin osallistumaan sähköpostitse kaikki ne työntekijät, joilla oli tiedossa toimiva työsähköpostiosoite ( $\mathrm{N}=25494)$. Lisäksi organisaation sisäverkossa pandemia-aiheisilla tiedotussivuilla oli kutsu osallistua tutkimukseen osallistumislinkkeineen. Sähköpostin tai avoimen linkin kautta osallistuneet antoivat ensin tietoon perustuvan suostumuksen ennen kyselyyn vastaamista. Kyselyyn vastaajat saavat joka vastauskierroksella tietoa organisaation tukitoimista, sekä koosteen vastaajan omista vastauksista hyvinvointikyselyyn, jonka avulla voi seurata omaa jaksamista pandemian edetessä.

Tutkimuksen ensimmäisessä vaiheessa (T0) 4.-20. kesäkuuta 2020 kyselyyn tuli 4840 vastausta, joista pieni osa oli duplikaatteja. Lopullinen T0 aineisto koostui N=4804 (19\% HUSin työntekijöistä) vastauksesta. Pääosa vastauksista tuli henkilökohtaisen sähköpostikutsun kautta. Kohderyhmästä oli käytettävissä työyksikkötiedot sekä ammattinimikkeet, jotka saatiin henkilöstöjohdosta. Kohderyhmän sukupuolijakauma oli naisia $84 \%$ ja miehiä $16 \%$. Vastanneista $62 \%$ oli hoitohenkilökuntaa, $9 \%$ lääkäreitä, $8 \%$ erityistyöntekijöitä ja $21 \%$ muuta henkilöstöä. Vastaajien iän keskiarvo oli 44,2 vuotta ja heistä $88 \%$ oli naisia, miehiä $11 \%$ ja muu sukupuoli tai ei halunnut ilmaista $1 \%$. Aineiston katoanalyysi esitetään tuloksissa.

Tutkimusta varten laadittu sähköinen kyselylomake (suomeksi ja ruotsiksi) sisälsi taustatietokysymysten lisäksi kysymyksiä COVID-19-pandemian aiheuttamista muutoksista työnkuvassa sekä kysymyksiä kuormittumisesta, osa avoimia kysymyksiä, ja psyykkisiä itsearviointiin perustuvia standardoituja oiremittareita. Erityisesti luokiteltiin vastausten perusteella, raportoiko vastaaja työssään tapahtuneen muutoksia COVID-19-pandemian takia (kyllä/ei) sekä oliko hän kuluneen viikon aikana ollut tekemisissä COVID-19-potilaiden tai sellaiseksi epäiltyjen kanssa (osallistunut välittömään potilashoitoon tai yhdistetty luokka muista vastauksista: osallistunut potilaiden välilliseen hoitoon, osallistunut hoidon järjestämiseen, en ole, en tiedä tai muu jossa vapaamuotoinen vastausmahdollisuus).

Sähköinen kyselylomake sisältää viisi eri oirekartoituskyselyä. Psyykkistä kuormittuneisuutta 
mitattiin Mental Health Index-5 kysymyssarjalla (MHI-5) (17). Siinä kysytään, kuinka suuren osan ajasta vastaaja on neljän (4) viime viikon aikana ollut hyvin hermostunut, tuntenut mielialansa niin matalaksi, ettei mikään ole voinut piristää, tuntenut itsensä tyyneksi ja rauhalliseksi, tuntenut itsensä alakuloiseksi ja apeaksi sekä ollut onnellinen. Vastausvaihtoehtoja kysymyksiin on kuusi.

Uniongelmia kartoitettiin Insomnia Severity Index (ISI) kysymyksillä (18) ja masennusoireita kahdella kysymyksellä (PRIME-MD) (19). Traumaattisia kokemuksia COVID-19-pandemiaan liittyen raportoineet pyydettiin lisäksi vastaamaan traumaperäisiä oireita kartoittavaan Primary Care PTSD Screen for DSM-5 kyselyyn (PC-PTSD-5) $(20,21)$ ja ahdistuneisuusoireiden haittaavuutta kartoittaviin Overall Anxiety Severity and Impairment Scale kysymyksiin (OASIS) $(22,23)$.

MHI-5 viiden hyvinvointia ja oireita kuvaavien kysymysten perusteella lasketut pisteet muutetaan asteikolle 0-100. Psyykkisesti kliinisesti merkittävästi kuormittuneiksi arvioidaan katkaisupisterajan 52 tai sen alle asteikolle sijoittuvat henkilöt $(M=73,3, S D=18,3)$. Tätä samaa pisterajaa on käytetty suomalaisissa väestötutkimuksissa (15).

ISI arvioi unettomuuden haittaa seitsemän kysymyksen sarjalla, summapisteet 0-28. 8-14 pistettä viittaa lievään unettomuuteen ja 15-28 keskivaikeaan tai vaikeaan unettomuuteen $(\mathrm{M}=7,3, \mathrm{SD}=5,3)$. PRIME-MD kartoittaa masennuksen riskiä kahdella kysymyksellä. Tässä käytettiin melko herkkää seularajaa, huolta kummasta tahansa masentuneesta mielialasta tai mielenkiinnon menetyksestä viimeisen kuukauden aikana, seulapositiivisuuden merkkinä mahdollisen masennusoireiston suhteen.

Potentiaalisesti traumaattisia kokemuksia (PTE) COVID-19-pandemiaan liittyen kartoitettiin neljällä kysymyksellä, joihin vastattiin kyllä tai ei: 1) Ovatko työtehtäväsi COVID-19 (epäilty tai varmistettu) -potilaiden hoitoon tai heidän kanssaan muuten työskentelyyn liittyen olleet poikkeuksellisen järkyttäviä tai kuormittavia? 2) Oletko ollut voimakkaasti ahdistunut omasta tai läheistesi vakavan sairastumisen riskistä johtuen työtehtävistäsi COVID-19 (epäilty tai varmistettu) -potilaiden hoitoon tai heidän kanssaan muuten työskentelyyn liittyen? 3) Oletko itse tai läheisesi tai omaisesi sairastanut vakavan, sairaalahoitoa vaatineen, COVID-19 sairauden? 4) Onko omaisesi tai läheisesi menehtynyt COVID-19 sairauteen? Kyllä vastaus mihin tahansa em. kysymyksistä johti traumaperäisten sekä ahdistusoireiden kartoittamiseen. PC-PTSD-5 arvioi traumaperäisiä takaumia, välttelyn, ylivireyden, turtumuksen ja negatiivisten kognitioiden oireita. Kolme kyllä vastausta viidestä katsotaan seulapositiiviseksi traumaperäisten oireiden suhteen. OASIS kartoittaa ahdistusoireiden esiintymistä ja niistä aiheutuvaa haittaa, summapisteet 0-20. Kahdeksaa pistettä käytettiin tässä katkaisupisterajana, joka seuloo mahdollista ahdistuneisuushäiriötä.

Lopuksi kysyttiin (kyllä/ei -asteikolla) vastaajan mahdollista kokemusta psyykkisen tuen tarpeesta ja oliko hän saanut tukea HUSin henkilöstön tukitoimien tai työterveyshuollon kautta.

Henkilöstöryhmät jaettiin analyysejä varten lääkäreihin, sairaanhoitajiin, sairaanhoitajien esimiehiin, muuhun hoitohenkilökuntaan, erityistyöntekijöihin ja muuhun henkilöstöön. HUSin organisaation vastuualueet tai linjat (jatkossa linjat), joista vähintään 20 henkilökunnan jäsentä oli vastannut kyselyyn, luokiteltiin ryhmiin sen mukaan, kuinka suuri osuus niiden henkilöstöstä oli osallistunut COVID-19 potilaiden tai epäiltyjen potilaiden hoitoon viimeisen viikon aikana. Linjat, joissa alle $15 \%$ henkilöstöstä oli osallistunut COVID-19-potilaiden hoitoon, luokiteltiin ensimmäiseen ryhmään. Seuraavat ryhmät muodostuivat vastaavasti linjoista, joissa alle $30 \%$, alle $45 \%$, alle $60 \%$ ja lopuksi yli $60 \%$ vastaajista oli osallistunut COVID-19-potilaiden hoitoon. Edelleen yksittäiset työntekijät luokiteltiin oman linjansa ryhmän mukaisesti. Tulokset esitetään parittaisten vertailujen taulukoissa, mukaan lukien khiin-neliö testit mahdollisten ryhmien välisten erojen merkitsevyyden tarkastelemiseksi.

Henkilöstö ryhmiteltiin lisäksi eri psyykkisten oireasteikkojen perusteella mahdollisen samanaikaissairastavuuden (komorbiditeetin) arvioimiseksi. Ryhmittely tehtiin kaksivaiheisella klusterianalyysillä (TwoStep Cluster Analysis) MHI-5 ja ISI summien sekä luokiteltujen masennusoireseulan ja COVID-19 liittyvien traumaattisten kokemusten perusteella. Paras ratkaisu ryhmien määrän suhteen ryhmittelymalli ratkaistiin mm. BIC arvon ja sen muutoksen perusteella. 
Ohjelmistona käytettiin IBM SPSS Statistics for Windows, Version 26.0 ja 27.0 (Armonk, NY, USA: IBM Corp.). Tilastollisen merkitsevyyden raja-arvoksi asetettiin p:n arvo $<0,05$.

Kuvaamme tulososiossa myös HUSlaisen esihenkilön empiirisiä havaintoja COVID-19-pandemian vaikutuksesta hoitohenkilökuntaan, määrällisen tutkimuksen tulosten taustalla olevien tapahtumien ja kokemusten esille tuomiseksi.

HUSin II eettinen toimikunta on antanut tutkimuksesta puoltavan lausunnon $(\$ 119 / 6.5 .2020$, HUS/1488/2020) ja tutkimukselle on saatu tutkimuslupa HUSin Sairaanhoidon ja palvelutuotannon johdon vastuualueelta ( $\$ 52$ HUS/157/2020 01.06.2020).

\section{TULOKSET}

Tutkimukseen osallistuneet edustivat HUSin henkilöstöä ja vastanneita verrattiin koko HUSin henkilöstön tietoihin toukokuun 2020 lopussa. Naiset vastasivat miehiä merkittävästi useammin kyselyyn $(\mathrm{p}<0,001)$. Ikäryhmistä 45-54-vuotiaat vastasivat useammin $(27,2 \%$ vastanneista, ko. ikäryhmä 24,0 \% koko henkilöstöstä) ja 25-34vuotiaat harvemmin (20,9\% vastanneista, ko. ikäryhmä 23,7 \% koko henkilöstöstä) verrattuna muihin ikäryhmiin. Hoitohenkilökunnasta kyselyyn vastasi $20,6 \%$, lääkäreistä $12,2 \%$, erityistyöntekijöistä $17,5 \%$ ja muusta henkilöstöstä $13,8 \%$. Sairaanhoitoalueittain, mukaan lukien Diagnostiikkakeskus, vastanneiden prosenttiosuudet vaihtelivat Porvoon sairaanhoitoalueen $14,7 \%$ ja HYKS sairaanhoitoalueen 18,6\% välillä. Muiden toimintojen osalta matalin vastausprosentti on Logistiikassa $12,2 \%$ ja korkein Työterveydessä 36,8 \%. Suurimman HYKS sairaanhoitoalueen linjojen vastausprosentit vaihtelivat huomattavasti, vastuualueiden välisen vastausprosentin mediaanin ollessa 18,3\%. Niillä linjoilla, joissa henkilöstä alle $15 \%$ oli osallistunut COVID-19 potilaiden tai epäiltyjen potilaiden hoitoon viimeisen viikon aikana $15,3 \%$ oli vastannut kyselyyn, muiden ryhmien vastausosuuksien ollessa tasaisesti 18,3\% ja 19,6 \% välillä.

Työnkuvassa oli tapahtunut muutoksia COVID-19 -pandemian vuoksi valtaosalla eri henkilöstöryhmistä, osuudet vaihtelivat 72-88 \%:n välillä (taulukko 1). COVID-19-potilaiden hoitoon oli osallistunut suurempi osuus sairaanhoitajista ja muusta hoitohenkilökunnassa (39-41\%) kuin muista henkilöstöryhmistä. Psyykkistä oireilua kliinisesti merkittävän kuormittuneisuuden (MHI-5), keskivaikean tai vaikean unettomuuden (ISI) ja masennusriskin seulan (PRIME-MD) avulla arvioituna oli useammin sairaanhoitajilla ja muulla hoitohenkilökunnalla (taulukko 1). Vähintään lievää unettomuutta oli sairaanhoitajista ja muusta hoitohenkilökunnasta noin $46 \%$ :lla, sairaanhoitajien esimiehistä noin $39 \%: 11$ a, lääkäreistä $33 \%: 1 l a$, erityistyöntekijöistä $40 \%: 1 l a$ ja muusta henkilöstöstä $41 \%$ :lla.

Erään HUSin esihenkilön kokemuksia COVID-19-pandemian aiheuttamista toiminnan ja työnkuvien muutoksista; Olin aloittanut esimiehenä leikkausosastolla. Työt alkoivat juuri sujua undessa tehtävässä, kun COVID-19 saapui Suomeen. Kukaan ei tuntunut tietävän, mistä on kyse ja miten pitäisi toimia. Maaliskuussa oli ilmeistä, että kiireetöntä leikkaustoimintaa oli ajettava alas ja henkilökuntaa siirrettävä tehojen avuksi. Sitä ennen leikkauksia kuitenkin piti tehdä entiseen tapaan. Yritimme hoitaja- ja lääkäriesimiehistön kanssa saada hoitajille perehtymisaikaa tehotyöhön.

Hoitajia yritettiin rauhoitella ja pitää mahdollisuuksien mukaan ajan tasalla joka aamuisilla lyhyillä infotilaisuuksilla. Henkilökunta oli buolissaan ja peloissaan, samoin esimiehet. Omaa pelkoa ei kuitenkaan voinut näyttää ulospäin. Halusin olla vahva, olla muiden tukena ja saatavilla mahdollisimman paljon. Ylityötunteja tuli valtavasti. Joka päivä odotimme lupaa supistaa leikkaustoimintaa ja päästä harjoittelemaan teholle. Esimiehe$n \ddot{a}$ kuulin hoitajien kokemuksista päivittäin. Heillä oli esimerkiksi pelkoa siitä, etteivät osaa. Potilaat olivat huonossa kunnossa ja useita menehtyi. Kaiken aikaan lisäubkana mielessä oli oman ja läheisten sairastumisen ubka ja pelko. Vuorot olivat raskaita ja osasto oli lähes koko ajan täynnä. Hoitajia oli vähän. Eristysvaatteissa ja suojaimissa oli kuuma. Suojavarusteita oli myös aluksi niin vähän saatavilla, ettei tauolla voinut käydä kuin kerran työvuoron aikana.

Vähintään yhden potentiaalisesti traumaattisen kokemuksen (PTE) COVID-19-pandemiaan liit- 
Taulukko 1. Työnkuvan muutokset COVID-19-pandemiaan liittyen sekä psyykkinen oireilu henkilöstöryhmittäin

\begin{tabular}{|c|c|c|c|c|c|c|c|}
\hline & $\begin{array}{l}\text { Lääkärit } \\
\mathrm{N}=425\end{array}$ & $\begin{array}{l}\begin{array}{c}\text { Sairaan- } \\
\text { hoitajat }\end{array} \\
\mathrm{N}=1896\end{array}$ & $\begin{array}{l}\text { Sairaan- } \\
\text { hoitajien } \\
\text { esimiehet } \\
\mathrm{N}=327 \\
\end{array}$ & $\begin{array}{c}\text { Muu hoito- } \\
\text { henkilö- } \\
\text { kunta } \\
\mathrm{N}=795 \\
\end{array}$ & $\begin{array}{c}\begin{array}{c}\text { Erityis- } \\
\text { työntekijät }\end{array} \\
\mathrm{N}=377 \\
\end{array}$ & $\begin{array}{c}\begin{array}{c}\text { Muu } \\
\text { henkilöstö }\end{array} \\
\mathrm{N}=972 \\
\end{array}$ & \\
\hline & \multicolumn{6}{|c|}{ \% ammattiryhmästä } & $\mathrm{p}$ \\
\hline $\begin{array}{l}\text { Työssä muutoksia } \\
\text { pandemiasta johtuen }\end{array}$ & 86,7 & 88,0 & 79,1 & 83,7 & 76,3 & 71,7 & $<0,001$ \\
\hline $\begin{array}{l}\text { Osallistunut } \\
\text { COVID-19- } \\
\text { potilaiden tai } \\
\text { epäiltyjen potilaiden } \\
\text { hoitoon }\end{array}$ & 22,7 & 40,5 & 10,4 & 38,8 & 3,2 & 1,1 & $<0,001$ \\
\hline $\begin{array}{l}\text { Masennusoireet } \\
\text { (PRIME-MD } \\
\text { seulapositiivinen) }\end{array}$ & 23,0 & 34,6 & 28,0 & 35,2 & 29,8 & 31,4 & $<0,001$ \\
\hline $\begin{array}{l}\text { Merkittävä } \\
\text { psyykkinen } \\
\text { kuormittuneisuus } \\
\text { (MHI-5) }\end{array}$ & 9,7 & 19,8 & 12,1 & 19,7 & 11,5 & 14,8 & $<0,001$ \\
\hline $\begin{array}{l}\text { Uniongelmat (ISI) } \\
\text { lievä unettomuus } \\
\text { keskivaikea tai } \\
\text { vaikea unettomuus }\end{array}$ & $\begin{array}{c}26,5 \\
6,4\end{array}$ & $\begin{array}{l}34,4 \\
11,8\end{array}$ & $\begin{array}{l}30,2 \\
8,5\end{array}$ & $\begin{array}{l}34,9 \\
11,1\end{array}$ & $\begin{array}{c}32,8 \\
6,7\end{array}$ & $\begin{array}{l}32,1 \\
9,3\end{array}$ & $<0,001$ \\
\hline $\begin{array}{l}\text { Vähintään yksi } \\
\text { COVID-19 liittyvä } \\
\text { potentiaalisesti } \\
\text { traumaattinen } \\
\text { kokemus (PTE) }\end{array}$ & 14,9 & 38,6 & 19,1 & 30,0 & 14,8 & 16,7 & $<0,001$ \\
\hline $\begin{array}{l}\text { Traumaoireet } \\
\text { (PC-PTSD-5 } \\
\text { seulapositiivinen) }\end{array}$ & 14,5 & 24,2 & 16,1 & 27,1 & 26,4 & 21,2 & 0,202 \\
\hline $\begin{array}{l}\text { Haittaavat } \\
\text { ahdistusoireet } \\
\text { (OASIS } \\
\text { seulapositiivinen) }\end{array}$ & 19,4 & 28,4 & 19,4 & 29,4 & 40,4 & 33,5 & 0,059 \\
\hline $\begin{array}{l}\text { On kokenut tarvetta } \\
\text { psyykkiselle tuelle, } \\
\text { viimeinen kuukausi }\end{array}$ & 12,0 & 19,1 & 18,9 & 17,1 & 15,3 & 11,6 & $<0,001$ \\
\hline $\begin{array}{l}\text { On saanut tukea } \\
\text { henkilöstön } \\
\text { hyvinvointiprojektin } \\
\text { tai muuten } \\
\text { organisaation } \\
\text { kautta, viimeinen } \\
\text { kuukausi }\end{array}$ & 3,3 & 8,6 & 12,3 & 7,3 & 8,5 & 9,9 & $<0,001$ \\
\hline
\end{tabular}

tyen raportoi reilu neljännes HUSin henkilöstöstä (n=1296, 27,8 \%). Työhön liittyvissä kysymyksissä sairaanhoitajat raportoivat useammin traumaattisia kokemuksia kuin muu henkilöstö. Poikkeuksellisen järkyttäviä ja kuormittavia työtehtäviä tuli esille sairaanhoitajien vastauksissa 22,0 \%:1la ( $\mathrm{n}=411)$, muulla hoitohenkilökunnalla $12,7 \%$ :lla $(\mathrm{n}=99)$, matalimman osuuden olles- sa erityistyöntekijöillä 2,8 \%:lla $(\mathrm{p}<0,001)$. Voimakasta ahdistuneisuutta omasta tai läheisten sairastumisen riskistä työtehtävistä johtuen kuvasi hiukan suurempi osuus sairaanhoitajista ( $\mathrm{n}=507,27,1 \%$ ) kuin muusta hoitohenkilökunnasta $(\mathrm{n}=188,24,1 \%)$, muiden henkilöstöryhmien osuuksien ollessa pienemmät $(9,8-13,0 \%$, $\mathrm{p}<0,001)$. Oman tai läheisen vakavan sairaala- 
hoitoa vaatineen sairastumisen raportoi 2,8\% ( $n=134)$ ja tässä ei ollut henkilöstöryhmien välillä eroja $(\mathrm{p}=0,431)$. Omaisen tai läheisen menehtymisen COVID-19-sairauteen kuvasi 0,8\% $(\mathrm{n}=39)$ ja ryhmien välillä ei ollut eroja $(\mathrm{p}=0,671)$. Traumaperäisiä oireita oli niistä, jotka kuvasivat vähintään yhden traumaattisen kokemuksen, vajaalla neljäsosalla $(14,5-27,1 \%)$ ja huomattavaa ahdistuneisuutta reilulla neljäsosalla $(19,4-$ $40,4 \%$ ) (taulukko 1).

HUSin henkilöstön oireiden tarkastelu henkilön linjan (vastuualueen) COVID-19-potilaita tai epäiltyjä potilaita hoitaneiden osuuteen verrattuna toi esille eroja kuormittuneisuudessa (taulukko 2). Psyykkistä oireilua kliinisesti merkittävän kuormittuneisuuden (MHI-5), keskivaikean tai vaikean unettomuuden (ISI) ja masennusriskin seulan (PRIME-MD) perusteella arvioituna oli useammin niillä työntekijöillä, joiden linjan (vastuualueen) henkilökunnasta 30,0-44,9 \% ja 45,0-59,9\% oli hoitanut COVID-19-potilaita. Sen sijaan linjoilla (tai vastuualueilla), jossa hoitaneiden osuus oli pienempi - tai suurempi $(>60,0 \%)$, oireilevien osuudet olivat pienemmät (taulukko 2).

Henkilöt, joiden linjalla COVID-19-potilaiden hoitoon osallistui suurempi osuus, raportoivat useammin kuin muut vähintään yhden traumaattisen kokemuksen (PTE) COVID-19pandemiaan liittyen. Sen sijaan henkilöstöstä traumaperäisiä oireita PTE:n seurauksena koki suurempi osuus heistä, joiden linjan henkilökunnasta $30,0-44,9 \%$ ja $45,0-59,9 \%$ oli hoitanut COVID-19-potilaita ja pienin osuus yli $60 \%$ COVID-19-potilaita hoitaneista (taulukko 2).

Taulukko 2. Työnkuvan muutokset COVID-19-pandemiaan liittyen sekä psyykkinen oireilu suhteessa henkilön linjan (tai vastuualueen) COVID-19-potilaita tai epäiltyjä potilaita hoitaneiden osuuteen ${ }^{1}$

\begin{tabular}{|c|c|c|c|c|c|c|}
\hline & $\begin{array}{c}0,0-14,9 \% \\
\mathrm{~N}=1147\end{array}$ & $\begin{array}{c}15,0-29,9 \% \\
\mathrm{~N}=942\end{array}$ & $\begin{array}{c}30,0-44,9 \% \\
\mathrm{~N}=848\end{array}$ & $\begin{array}{c}45,0-59,9 \% \\
\mathrm{~N}=797\end{array}$ & $\begin{array}{l}60,0-\% \\
\mathrm{~N}=221\end{array}$ & \\
\hline & & & \% ryhmästä & & & $p$ \\
\hline $\begin{array}{l}\text { Osallistunut COVID-19- } \\
\text { potilaiden tai epäiltyjen } \\
\text { potilaiden hoitoon }\end{array}$ & 2,5 & 22,3 & 37,9 & 50,9 & 72,9 & \\
\hline $\begin{array}{l}\text { Masennusoireet } \\
\text { (PRIME-MD seulapositiivinen) }\end{array}$ & 33,1 & 26,7 & 38,0 & 37,5 & 27,3 & $<0,001$ \\
\hline $\begin{array}{l}\text { Merkittävä psyykkinen } \\
\text { kuormittuneisuus } \\
\text { (MHI-5) }\end{array}$ & 16,3 & 11,6 & 23,5 & 21,4 & 13,2 & $<0,001$ \\
\hline $\begin{array}{l}\text { Uniongelmat (ISI) } \\
\text { lievä unettomuus } \\
\text { keskivaikea tai vaikea } \\
\text { unettomuus }\end{array}$ & $\begin{array}{l}33,2 \\
9,8\end{array}$ & $\begin{array}{l}31,7 \\
8,0\end{array}$ & $\begin{array}{l}37,2 \\
13,2\end{array}$ & $\begin{array}{l}34,2 \\
12,9\end{array}$ & $\begin{array}{l}26,9 \\
9,7\end{array}$ & $<0,001$ \\
\hline $\begin{array}{l}\text { Vähintään yksi COVID-19 } \\
\text { liittyvä potentiaalisesti } \\
\text { traumaattinen kokemus (PTE) }\end{array}$ & 17,4 & 23,2 & 39,5 & 40,6 & 36,2 & $<0,001$ \\
\hline $\begin{array}{l}\text { Traumaoireet } \\
\text { (PC-PTSD-5 } \\
\text { seulapositiivinen) }\end{array}$ & 24,4 & 19,2 & 28,6 & 25,9 & 13,9 & 0,023 \\
\hline $\begin{array}{l}\text { Haittaavat ahdistusoireet } \\
\text { (OASIS seulapositiivinen) }\end{array}$ & 36,1 & 26,6 & 30,4 & 29,4 & 11,3 & 0,001 \\
\hline $\begin{array}{l}\text { On kokenut tarvetta } \\
\text { psyykkiselle tuelle, viimeinen } \\
\text { kuukausi }\end{array}$ & 16,2 & 16,2 & 20,3 & 17,7 & 13,4 & 0,051 \\
\hline $\begin{array}{l}\text { On saanut tukea henkilöstön } \\
\text { hyvinvointiprojektin tai } \\
\text { muuten organisaation kautta, } \\
\text { viimeinen kuukausi }\end{array}$ & 9,2 & 6,9 & 10,4 & 7,4 & 8,8 & 0,062 \\
\hline
\end{tabular}

${ }^{1}$ Vain ne vastuualueet/linjat on luokiteltu, joissa vähintään 20 henkilöä on vastannut kyselyyn. 
Erään HUSin esihenkilön havaintoja henkilöstön oireilusta; Yleisesti kolmivuorotyö koettiin raskaana ja hoitajia oli jatkuvasti paljon sairaina. Henkilökunta oli tehojakson aikana järkyttynyttä ja väsynyttä. Oli sekä fyysisiä että henkisiä oireita, kuten poissaoloja, unettomuutta ja paniikkioireita. Toisaalta muutama oli undesta tehtävänkuvasta jopa innoissaan ja jaksoi venyä ja tehdä ylimääräisiä työvuoroja.

Tutkimme, miten henkilöstö ryhmittyy eri psyykkisten oireasteikkojen perusteella kaksivaiheisella klusterianalyysillä. Neljän eri ryhmän malli oli paras ratkaisu. Masennusoireiden suhteen seulapositiivisuus ja toisaalta pandemian vuoksi työssä ilmennyt trauma-altistus käytännössä ohjasivat ryhmien muodostumista. Suurimman ryhmän $(54,3 \%)$ muodostivat he, jotka raportoivat harvoin oireita, 17,9\%:lla oli psyykkistä oireilua ilman pandemiaan liittyviä traumaattisia kokemuksia, 14,6 \%:lla oli pandemiaan liittyviä traumaattisia kokemuksia ja oireilua voimakkaimmin eri oiremittareilla raportoituna ja 13,2 \%:lla oli pandemiaan ja työhön liittyviä traumaattisia kokemuksia, mutta heillä oli melko vähän oireita.

Psyykkisen tuen tarvetta viimeisen kuukauden aikana oli kokenut noin $16 \%(n=774)$ ja tukea hyvinvointiprojektista tai muutoin organisaation kautta oli saanut noin $8 \%(n=397)$. Tuen tarvetta kokeneista 21,5\% oli saanut tai ottanut vastaan tukea (taulukko 3). Tuen tarvetta koki jonkin verran suurempi osuus niistä, joiden työssä oli tapahtunut muutoksia pandemiaan liittyen kuin niistä, joilla ei ollut ollut muutoksia. COVID-19-potilaiden hoitoon osallistuneista hiukan suurempi osuus koki tuen tarvetta kuin tähän työhön ei osallistuneista.

Psyykkistä kuormittuneisuutta kokeneiden ja unettomuutta kokeneiden ryhmien välillä oli eroa psyykkisen tuen tarpeen kokemuksessa, psyykkisesti kuormittuneiden raportoidessa useammin tuen tarvetta kuin unettomuudesta kärsivät. Tuen tarvetta psyykkisesti kuormittuneista koki $52,2 \%$ ja ei kuormittuneista 9,2\%, vastaavasti vähintään merkittävästi unettomista 27,3\% (keskivaikeasti tai vaikeasti unettomista 44,6 \%) ja ei unettomuutta raportoineista $8,5 \%$ koki tuen tarvetta. Tuen saamisessa ero ei ollut selkeä varsinkin, jos verrataan keskivaikeasti tai vaikeasti unettomia psyykkisesti kuormittuneisiin. Tukea oli saanut henkilöstön hyvinvointiprojektin tai muuten organisaation kautta $14,1 \%$ psyykkistä kuormittuneisuutta kokeneista ja 7,3 \% ei kuormittuneista. Vastaavasti tukea oli saanut 9,8\% merkittävästi unettomista $(14,9 \%$ keskivaikeasti tai vaikeasti unettomista) ja 7,3\% ei unettomuutta raportoineista. Psyykkinen kuormittuneisuus ja unettomuus esiintyi odotetusti osin samoilla henkilöillä. Samanaikaisesti psyykkises-

Taulukko 3. Tuen tarpeen kokemus ja saatu tuki sekä työnkuvan muutokset pandemiaan liittyen

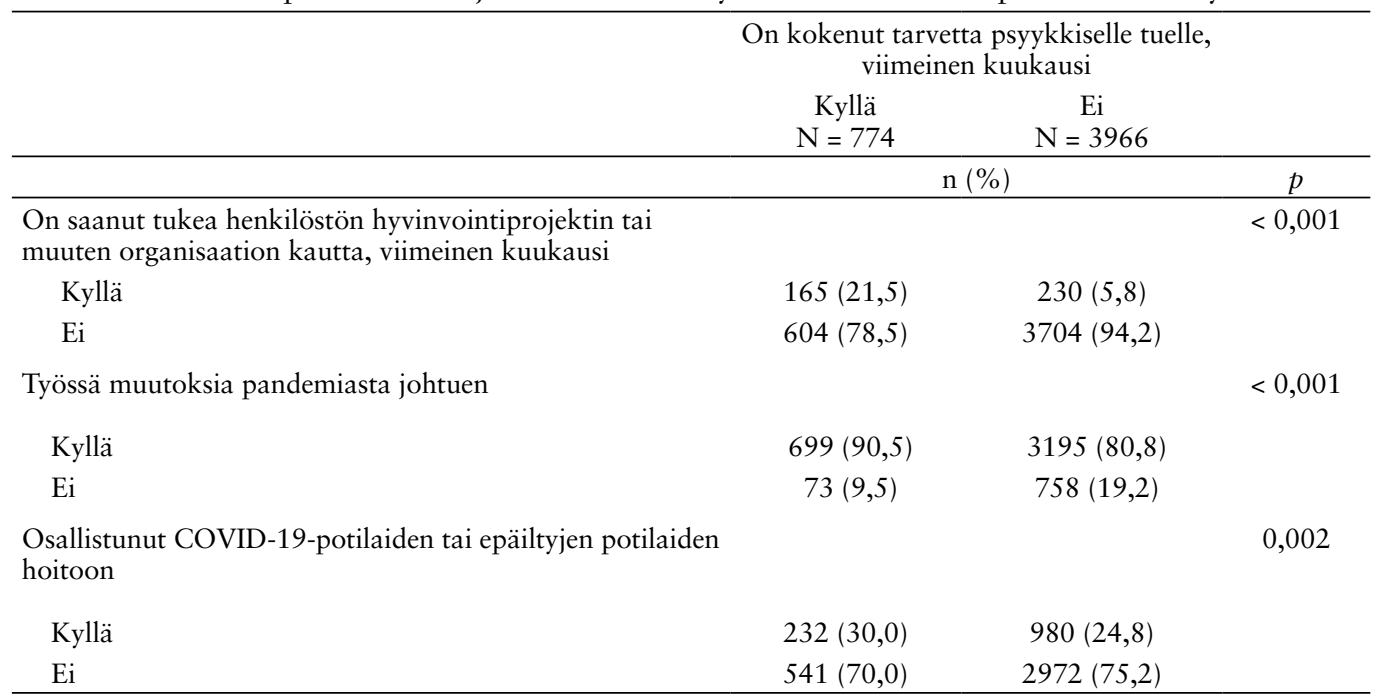


ti kuormittuneista ja merkittävästi unettomista, joita oli 641, 55,3\% koki psyykkisen tuen tarvetta. Samanaikaisesti psyykkisesti kuormittuneista ja keskivaikeasti tai vaikeasti unettomista, joita oli 280, 60,7 \% koki tuen tarvetta. Tukea saaneiden osuudet olivat vastaavasti $15,2 \%$ ja $17,9 \%$.

Erään HUSin esihenkilön kokemuksia selviytymisestä ja tuen saamisesta COVID-19-pandemian alkuvaiheessa; Olen jälkikäteen ajatellut, etten ymmärtänyt henkilökunnan ahdistusta aluksi täysin. Ymmärrykseni hoitajien kokemuksista lisääntyi pikkubiljaa kevään aikana. Olin itsekin avuton tilanteessa, jossa kaikki tapahtui hyvin nopeasti. Objeet muuttuivat jatkuvasti, pubelin soi ja sähköpostia tuli paljon. Yritin selvitä ja pysyä asioista kartalla. Tietoa, muutoksia, objeita ja epätoivoa oli niin paljon, että mietin niitä usein työpäivien lisäksi kotona. Myös öisin. Nukuin suurimman osan ajasta pienissä pätkissä ja olin uupunut itsekin. Sen olen ymmärtänyt vasta jälkeenpäin. Se on varmaankin ollut itselle yksi keino selviytyä pahimman yli. Sain kovasti apua jaksamiseeni kevään aikana omalta mieheltäni ja muntamilta hyviltä ystäviltä. Keskustelu ja kävely olivat lähinnä terapiakeinojani. Töissä sain kaikissa tilanteissa tukea omalta esimieheltäni ja muilta esimiehiltä. Toukokuun alussa palasimme omalle osastollemme, jossa normaalitoiminta käynnistettiin heti. Kenellekään ei jäänyt aikaa hengähtää. Väsymyksen jälkeen alkoi kiukku ja moni asia koettiin epäreiluksi. Osa hoitohenkilökunnasta hakeutui jälkikäteen toisenlaiseen työhön tai opiskelemaan. Mietin usein, riittääkö sitoutunutta ja osaavaa henkilökuntaa normaaliaikana? Entä silloin kun seuraava pandemia tulee? Toiveena kaikilla oli ensimmäisen aallon jälkeen, ettei samaan tilanteeseen jouduta enää koskaan.

Psyykkisen tuen tarvetta oli kokenut sairaanhoitajista $19,1 \%$ ja sairaanhoitajien esimiehistä $18,9 \%$, muissa henkilöstöryhmissä tuen tarvetta raportoitiin 11,6-17,1 \%:n välillä (taulukko 1). Tukea oli henkilöstön hyvinvointiprojektista tai muuten organisaation kautta useimmin saaneet sairaanhoitajien esimiehet $(12,3 \%)$ ja muu henkilöstö sekä erityistyöntekijät ollen seuraavaksi eniten tukea saaneiden ryhmät ja vasta tämän jälkeen sairaanhoitajat $(8,6 \%)$, vähiten tukea saaneiden ryhmä oli lääkärit $(3,3 \%)$. Henkilöstöryhmittäin eriteltynä tuen tarvetta kokeneista lääkäreistä 14,0 \% oli saanut tukea henkilöstön hyvinvointiprojektista tai muuten organisaation kautta, sairaanhoitajista 21,2 \%, sairaanhoitajien esimiehistä $28,3 \%$, muusta hoitohenkilökunnasta $18,7 \%$, erityistyöntekijöistä $25,0 \%$ ja muusta henkilöstöstä 23,9 \%. Tuki ei ollut kohdentunut yhdenvertaisesti tuen tarvetta kokeneilla vaan siinä oli henkilöstöryhmittäisiä eroja.

\section{POHDINTA}

Terveydenhuollon kantokyky ja eräiden erityisammattiryhmien, kuten tehohoitoa osaavan hoitohenkilöstön riittävyys ovat nousseet toistuvasti huolenaiheena esiin COVID-19-pandemian pitkittyessä myös Suomessa. Tarkastelimme yliopistosairaalan henkilöstön psyykkistä kuormitusta suhteessa työnkuvan muutoksiin sekä koettua tuen tarvetta ja saatua tukea $(15,16)$. Työnkuvan muutokset olivat erittäin yleisiä pandemian alkuvaiheessa. Erityisesti henkilöstö, jonka työ muuttui paljon COVID-19-pandemian vuoksi, raportoi useammin psyykkisiä oireita, vähiten ja eniten COVID-19-potilaita hoitaneisiin ryhmiin verrattuna. Ryhmittelyä tarkastellessa yli $60 \%$ ryhmään sijoittuu päivystystoimintoja, 45,0-59,9\% ryhmään sijoittuu mm. tehohoidon, keuhkosairauksien, sisätautien ja diagnostiikan toimintoja, 30,0-44,9 \% ryhmään leikkaussalitoimintoja sekä konservatiivisia osastohoidon toimintoja. Päivystyksessä työskentelyyn liittynee paljon eri potilaiden kohtaamisia, mutta pitkäkestoisesta ja raskaasta COVID-19-potilaiden hoidosta vastasivat kahden muun ryhmän toiminnot. Näillä linjoilla jouduttiin toimintoja myös laajemmin muuttamaan ja työnkuvissa tapahtui suurempia muutoksia.

Saman aineiston kuuden kuukauden seuranta korosti yksilöllisten tekijöiden merkitystä pidempiaikaisen kuormituksen yhteydessä (16), myös pandemian toinen aalto liittyi lisääntyneeseen kuormitukseen ja uniongelmiin. Mahdollisia yksilöllisiä tekijöitä ovat esimerkiksi aiempi psyykkinen oireilu, oma muu terveydentila, muu elämäntilannekuormitus, sekä hyvinvointia suojaavien tekijöiden, kuten sosiaalisen tuen puuttuminen ja resilienssi eli psyykkinen "kimmoisuus", kyky adaptoitua muuttuvaan tilanteeseen. 
Monimuotoinen oireseuranta on tarpeen riittävän kokonaiskuvan saamiseksi, mutta oirekyselyjen täyttäminen ei voi viedä pitkään kyselyn käytettävyyden varmistamiseksi poikkeusaikana, kuten pandemia (12). Tarkasteltaessa oirekartoituslomakkeita samoilla vastaajilla aineistossa erottui neljä erityyppistä oirekokonaisuusryhmää; psyykkisesti hyvinvoivat ja lieväoireiset työntekijät sekä poikkeuksellisen kuormituksen yhteydessä lievempiä ja vakavampia jälkioireita raportoivat. Erityisesti työntekijät joilla kaikki oirekyselyt olivat poikkeavia saattavat hyötyä psykososiaalisista tukitoimista (15). Suurin osa ihmisistä toipuu traumaattisistakin kokemuksista aktiivisessa seurannassa läheisten tuella, mutta toimintakykyä voidaan tukea ja toipumista nopeuttaa oireisiin oikea-aikaisesti kohdistetuilla näyttöön perustuvilla tukitoimilla ja tarvittaessa oireisiin fokusoidulla hoidolla. Kaikkia toimintakyvyn ylläpitämisen kannalta merkittäviä tekijöitä ei tavoiteta oirekyselyin. Esimerkiksi sosiaaliset kontaktit liittyivät vähäisempään masennusoireiluun pandemian aikana laajassa englantilaistutkimuksessa (25). On vielä epäselvää, erottuuko pandemia-ahdistus, jossa on mukana sekä pelko sairastumisesta, elämän muuttuminen ja sosiaalinen eristäytyminen, muusta ahdistuneisuusherkkyydestä oleellisesti. Uniongelmien osalta väestöstä keskimäärin on vielä osin ristiriitaista tutkimustietoa pandemian ajalta (2629). Tulokset psyykkisen kuormittuneisuuden lisääntymisestä COVID-19 pandemian aikana ovat pääosin linjassa sekä suomalaisen FinSote -tutkimuksen tulosten että kansainvälisten tutkimusten kanssa $(12,30,31)$. Hoitohenkilökunnasta valtaosa on naisia, kuten tämän tutkimuksen osallistujistakin. Tässä aineistossa erityisesti ensilinjan hoitohenkilöstö oli kuormittunutta alkuvaiheessa eikä iällä tai sukupuolella ollut vaikutusta asiaan (15) ja ensilinjan henkilöstön kuormitus pysyi korkeana muuhun henkilöstöön verrattuna kuuden kuukauden ajan (16). Pirkanmaalla merkittävää terveydenhuollon lisäkuormitusta ahdistuneisuutena ei ole raportoitu 2020 (32), mutta vastaava traumaattisten kokemusten merkitys tuli esiin norjalaistutkimuksessa terveydenhuoltohenkilöstöä koskien (33).

Muita terveydenhuoltopalveluita tukevan koko HUS-henkilöstölle sisäisellä verkkosivulla tarjolla olevan psykososiaalisen tuen palveluportaalin käyttömäärä on ollut noin puolet kaikkein kuormittuneimman henkilöstön määrästä (suullinen tiedonanto). Tässä pandemian alkuaikaan sijoittuvassa aineistossa noin viidesosa kuukauden sisään tukea tarvinneista oli saanut tukea. Suomalaisessa terveydenhuoltojärjestelmässä tukea voidaan hakea useita eri reittejä, joista kaikkia tämä kysely ei tavoita. Useissa medioissa jaksamisen haasteita sekä omia selviytymistapoja ja työyhteisöjen tukipalveluja on edelleen tuotu esiin pandemian toisen ja kolmannen aallon yhteydessä.

Tutkimuksen rajoitteita ovat oireiden itsearviointi ja se, että mukana on $19 \%$ organisaation henkilöstöstä ja ikäryhmistä nuoremmat aikuiset vastasivat harvemmin. Arvioimme, että mikäli aineistossa on valikoitumista, se liittyy mukana olevan henkilöstön kiinnostukseen tutkimusta kohtaan. Pandemian keskellä sähköinen kysely on toimiva tapa seurata tehokkaasti suurta joukkoa työntekijöitä ja tukitoimia voidaan myös järjestää sekä reaaliaikaisena että ei-reaaliaikaisena etäyhteyksin (34,35). Tutkimuskyselyä ei ollut mahdollista laajasti pilotoida tutkimusryhmän ulkopuolella pandemian alkuvaiheessa, joka olisi voinut vaikuttaa mukaan otettaviin muuttujiin. Toisaalta kyselyä ei käytettävyyden vuoksi olisi voinut laajentaa merkittävästi enempää aikaa vieväksi.

Tämän tutkimuksen aineiston myöhempi seuranta osoitti, että ajan kuluessa yksilöllisten tekijöiden merkitys ja myös alueen yleinen raportoitu COVID-19-esiintyvyys vaikuttavat kuormituskokemuksiin sekä yliopistosairaalan henkilöstöllä että esiintyvyyden muuttuessa kuormitukseen väestössä yleisesti (16). Koettu henkilöstön psyykkinen kuormitus COVID -19 -pandemiaaikana ei kaikissa tutkimuksissa ole liittynyt COVID-19-pandemiatyöhön. Mahdollisesti tässä tutkimuksessa havaittu työnkuvan muutoksiin assosioituva psyykkinen oireilu voi toimia yhtenä selittävänä tekijänä poikkileikkaustutkimusten eroja arvioitaessa (34,36-39).

\section{JOHTOPÄÄTÖKSET}

Työtehtävien muuttuminen COVID-19 -pandemiasta aikana altisti osan henkilöstöstä poikkeavalle kuormitukselle. COVID-19-pandemian pitkittyessä henkilöstön hyvinvointia tulee edelleen seurata. Lyhyt sähköinen kysely, jossa annetaan tietoa psykososiaalisista tukipalveluista, on siihen toimiva työkalu 


\section{KIITOKSET:}

Linjajohtaja Pekka Jylhä, osastonylilääkäri Katinka Tuisku, Hus psykiatria, Henkilöstöpäällikkö Anne Kujala, HUS

\section{RAHOITTAJAT:}

Hus psykiatria, tutkimusrahoitus 2021 (Tanja Laukkala)

\section{KIRJOITTAJIEN KONTRIBUUTIOT:}

Kaikki kirjoittajat ovat osallistuneet artikkelin suunnitteluun. Haravuori on tehnyt tilastoajot. Suvisaari on kommentoinut ne sekä koko käsikirjoituksen useita kertoja. Pellikka on kirjoittanut erillisosion käsikirjoitukseen. Junttila ja Haapa ovat koonneet aineiston ja osallistuneet sen analysointiin sekä kommentoineet käsikirjoituksen useita kertoja. Laukkala on kirjoittanut artikkelin ensimmäisen version ja korjannut artikkelin. Kaikki kirjoittajat ovat hyväksyneet käsikirjoituksen viimeisen version.

\footnotetext{
Haravuori, H., Suvisaari, J., Pellikka,A., Junttila, K., Haapa,T*., Laukkala, T*. Psychological distress among the Helsinki University Hospital personnel in the early stages of the COVID-19 Pandemic. Sosiaalilääketieteellinen aikakauslehti - Journal of Social Medicine 202 I: 58: 337-348.
}

Healthcare capacity has been of concern during the Covid -19 pandemic. In the early stages of the pandemic, work changes were frequent and internationally, there was concern also on the psychological well -being of health care personnel. A majority of the Covid -19 patients in Finland have been cared for in the HUS Helsinki University Hospital district. In June 2020, we assessed the well -being and psychological distress symptoms of the Helsinki University Hospital personnel with an electronic survey. In addition to psychological distress, the survey assesses insomnia, anxiety, depressive and stress -related symptoms and experiences on psychosocial support with structured symptom scales and open questions. Our aim was to evaluate the effect of work changes on psychological distress symptoms (assessed with Mental Health Index -5, MHI-5) in this study. The participants ( $\mathrm{N}=4804$, $19 \%$ of HUS personnel) reported high psychological distress among personnel caring for Covid
-19 patients for a longer period of time, assessing Covid -19 diagnoses and among personnel with moderate work changes. Those with most or least Covid -19-related patient work actually reported less psychological distress than those with moderate Covid -19 pandemic-related patient work. Of those who reported that they needed psychosocial support, one-fifth had received it by psychosocial support services provided by Hus, which were increased during the pandemic. It is important to assess psychological symptoms during pandemic -related work changes and to plan psychosocial support services as needed.

Keywords: Psychological distress, Covid- 19 pandemic, sleep, depressive symptoms, trauma and stress -related symptoms

\footnotetext{
Saapunut (11.03.2021)

Hyväksytty (28.08.2021)
}

\section{LÄHTEET}

1. Villani L, McKee M, Cascini F ym. Comparison of Deaths Rates for COVID-19 across Europe During the First Wave of the COVID-19 Pandemic. Frontiers in Public Health https://www.frontiersin.org/article/10.3389/ fpubh.2020.620416.

2. Tiirinki H, Tynkkynen LK, Sovala M ym. COVID-19 pandemic in Finland - Preliminary analysis on health system response and economic consequences. Health Policy Technol. 2020;9(4):649-662.
3. d'Ettorre G, Ceccarelli G, Santinelli L ym. Post-Traumatic Stress Symptoms in Healthcare Workers Dealing with the COVID-19 Pandemic: A Systematic Review. Int J Environ Res Public Health. 2021 Jan 12;18(2):601. doi: 10.3390/ijerph18020601.

4. Al Maqbali M, Al Sinani M, Al-Lenjawi B. Prevalence of stress, depression, anxiety and sleep disturbance among nurses during the COVID-19 pandemic: A systematic review and metaanalysis. J Psychosom Res. 2021 Feb;141:110343. doi:10.1016/j.jpsychores.2020.110343. 
5. Luo M, Guo L, Yu M ym. The psychological and mental impact of coronavirus disease 2019 (COVID-19) on medical staff and general public A systematic review and meta-analysis. Psychiatry Res. 2020;291:113190. doi:10.1016/j.psychres.2020.113190.

6. Vindegaard N, Benros ME. COVID-19 pandemic and mental health consequences: Systematic review of the current evidence. Brain Behav Immun. 2020 Oct;89:531-542. doi: 10.1016/j.bbi.2020.05.048.

7. Kisely S, Warren N, McMahon L ym. Occurrence, prevention, and management of the psychological effects of emerging virus outbreaks on healthcare workers: rapid review and meta-analysis. BMJ. 2020 May 5;369:m1642.

doi: 10.1136/bmj.m1642.

8. Salazar de Pablo G, Vaquerizo-Serrano J, Catalan A ym. Impact of coronavirus syndromes on physical and mental health of health care workers: Systematic review and meta-analysis. J Affect Disord. 2020 Oct 1;275:48-57. doi: 10.1016/j.jad.2020.06.022.

9. Salari N, Khazaie H, Hosseinian-Far A ym. The prevalence of stress, anxiety and depression within front-line healthcare workers caring for COVID-19 patients: a systematic review and meta-regression. Hum Resour Health. 2020 Dec 17;18(1):100. doi: 10.1186/s12960-020-00544-1.

10. Sanghera J, Pattani N, Hashmi Y ym. The impact of SARS-CoV-2 on the mental health of healthcare workers in a hospital setting-A Systematic Review. J Occup Health. 2020 Jan;62(1):e12175. doi: 10.1002/1348-9585.12175.

11. Zürcher SJ, Kerksieck P, Adamus C ym. Prevalence of Mental Health Problems During Virus Epidemics in the General Public, Health Care Workers and Survivors: A Rapid Review of the Evidence. Front Public Health. 2020 Nov 11;8:560389.

12. Pollock A, Campbell P, Cheyne J ym. Interventions to support the resilience and mental health of frontline health and social care professionals during and after a disease outbreak, epidemic or pandemic: a mixed methods systematic review. Cochrane Database of Systematic Reviews 2020, Issue 11. Art. No.: CD013779. DOI: 10.1002/14651858.CD013779.

13. Laukkala T, Tuisku K, Junttila K ym. COVID19-pandemian aiheuttama psyykkinen kuormitus terveydenhuollossa - seuranta on perusteltua. Lääketieteellinen Aikakauskirja Duodecim 2020;136(18):2005-12.

14. Häkkänen-Nyholm H, Lyytinen $\mathrm{N}$, Heinimaa $\mathrm{M}$ ym. Miten koronakriisi vaikuttaa terveydenhuollon työntekijöiden psyykkiseen hyvinvointiin? Suomen Lääkärilehti 2020;75(4344):2291-2294.

15. Haravuori $H^{*}$, Junttila $K^{*}$, Haapa $T$ ym. Personnel Well-Being in the Helsinki University Hospital during the COVID-19 Pandemic-A Prospective Cohort Study. Int. J. Environ. Res.
Public Health 2020, 17, 7905. https://doi.org/10.3390/ijerph17217905 .

16. Laukkala T, Suvisaari J, Rosenström T ym. COVID-19 Pandemic and Helsinki University Hospital Personnel Psychological Well-Being: SixMonth Follow-Up Results. Int. J. Environ. Res. Public Health 2021, 18, 2524. https://doi.org/10.3390/ijerph18052524 .

17. Rumpf HJ, Meyer C, Hapke U ym. Screening for mental health: Validity of the MHI-5 using DSMIV Axis I psychiatric disorders as gold standard. Psychiatry Res. 2001;105:243-253. doi: 10.1016/s0165-1781(01)00329-8.

18. Morin CM, Belleville G, Bélanger L ym. The Insomnia Severity Index: Psychometric indicators to detect insomnia cases and evaluate treatment response. Sleep. 2011;34:601-608. doi: 10.1093/sleep/34.5.601.

19. Arroll B, Khin N, Kerse N. Screening for depression in primary care with two verbally asked questions: Cross sectional study. BMJ. 2003;327:1144-1146 doi: 10.1136/bmj.327.7424.1144.

20. Norman SB, Cissell SH, Means-Christensen AJ ym. Development and validation of an overall anxiety severity and impairment scale (OASIS) Depress. Anxiety. 2006;23:245-249. doi: 10.1002/da.20182.

21. Bragdon LB, Diefenbach GJ, Hannan S ym. Psychometric properties of the Overall Anxiety Severity and Impairment Scale (OASIS) among psychiatric outpatients. J. Affect. Disord. 2016;201:112-115. doi: 10.1016/j.jad.2016.05.005.

22. Prins A, Bovin MJ, Kimerling R. The Primary Care PTSD Screen for DSM-5 (PC-PTSD-5). [Measurement Instrument]; 2015. Available online: https://www.ptsd.va.gov/professional/ assessment/screens/pc-ptsd.asp\#obtain.

23. Prins A, Bovin MJ, Smolenski DJ ym. The Primary Care PTSD Screen for DSM-5 (PCPTSD-5): Development and Evaluation within a Veteran Primary Care Sample. J. Gen. Intern. Med. 2016, 31, 1206-1211. doi: 10.1007/s11606-016-3703-5.

24. Viertiö S, Partanen A, Kaikkonen R ym. Palvelujen käyttö mielenterveyteen tai päihteiden käyttöön liittyvien ongelmien vuoksi Suomessa vuosina 2012-2015. Duodecim 2017;133(3):292300.

25. Sommerlad A, Marston L, Huntley J ym.. Social relationships and depression during the COVID-19 lockdown: longitudinal analysis of the COVID-19 Social Study [published online ahead of print, 2021 Jan 13]. Psychol Med. 2021;1-10. doi:10.1017/S0033291721000039.

26. Partinen M. Sleep research in 2020: COVID19-related sleep disorders. Lancet Neurol. 2021;20(1):15-17. doi:10.1016/S1474-4422(20)30456-7.

27. Partinen M, Bjorvatn B, Holzinger B ym.; ICOSS-collaboration group. Sleep and circadian 
problems during the coronavirus disease 2019 (COVID-19) pandemic: the International COVID-19 Sleep Study (ICOSS). J Sleep Res. 2021 Feb;30(1):e13206.

doi: 10.1111/jsr.13206.

28. AMHSI Research Team; Milken Research Team, Roitblat Y, Burger J, Leit A ym. Stayat-home circumstances do not produce sleep disorders: An international survey during the COVID-19 pandemic. J Psychosom Res. 2020 Dec;139:110282. doi: 10.1016/j.jpsychores.2020.110282.

29. Cop Beck F, Léger D, Fressard L ym; Coconel Group. Covid-19 health crisis and lockdown associated with high level of sleep complaints and hypnotic uptake at the population level. J Sleep Res. 2021 Feb;30(1):e13119. doi: 10.1111/jsr.13119.

30. Parikka S, Koskela T, Ikonen J ym. 2021 Aikuisväestön hyvinvointi, terveys ja palvelut FinSote 2020 : Aikuisten palvelukokemuksissa ja hyvinvoinnissa alueellisia eroja. Saatavana https:// www.julkari.fi/handle/10024/142634 luettu 5.6.2021 .

31. Suvisaari J, Appelqvist -Schmidlechner K, Solin $\mathrm{P}$ ym. Aikuisväestön mielenterveys ja avun hakeminen mielenterveysongelmiin - FinSote 2020.Tutkimuksesta tiiviisti 42/2021. Terveyden ja hyvinvoinnin laitos, Helsinki. Saatavana https://www.julkari.fi/handle/10024/142888 luettu 10.8.2021 .

32. Mattila E, Peltokoski J, Neva MH ym. COVID-19: anxiety among hospital staff and associated factors. Ann Med. 2021 Dec;53(1):237-246. doi: 10.1080/07853890.2020.1862905.

33. Johnson SU, Ebrahimi OV, Hoffart A. PTSD symptoms among health workers and public service providers during the COVID-19 outbreak. PLoS One. 2020;15(10):e0241032. Published 2020 Oct 21. doi: 10.1371/journal.pone.0241032.

34. Hummel S, Oetjen N, Du J ym. Mental Health Among Medical Professionals During the COVID-19 Pandemic in Eight European Countries: Cross-sectional Survey Study. J Med Internet Res. 2021 Jan 18;23(1):e24983. doi: $10.2196 / 24983$.

35. Strudwick G, Sockalingam S, Kassam I ym. Digital Interventions to Support Population Mental Health in Canada During the COVID-19 Pandemic: Rapid Review. JMIR Ment Health. 2021 Mar 2;8(3):e26550. doi: 10.2196/26550.
36. Hu D, Kong Y, Li W ym. Frontline nurses burnout, anxiety, depression, and fear statuses and their associated factors during the COVID-19 outbreak in Wuhan, China: A large-scale crosssectional study. EClinicalMedicine 2020; 24 : 1-10: doi: 10.1016/j.eclinm.2020.100424.

37. Labrague LJ, de Los Santos JAA. Fear of COVID-19, psychological distress, work satisfaction and turnover intention among frontline nurses. J Nurs Manag. 2020 Sep 27:10.1111/jonm.13168. doi: 10.1111/jonm.13168.

38. Pappa S, Ntella V, Giannakas T ym. Prevalence of depression, anxiety, and insomnia among healthcare workers during the COVID-pandemic: A systematic review and meta-analysis. Brain Behav Immun. 2020 Aug;88:901-907. doi: 10.1016/j.bbi.2020.05.026. Epub 2020 May 8. Erratum in: Brain Behav Immun. 2021 Feb;92:245.

39. Selander K, Nikunlaakso R, Sipponen J ym. 2021. Sosiaali- ja terveysalan ammattilaisten kasautuva koronakuorma: kyselytutkimus Suomen tilanteesta syksyllä 2020. Tutkiva Hoitotyö 19(2), $30-37$.

Henna Haravuori

Dos., vieraileva tutkija

THL

JaAna Suvisaari

Tutkimusprofessori

THL

Anu PellikKa

Osastonhoitaja, HtM

HUS, ATeK, Anestesia- ja leikkausosasto

KRISTIINA JUNTTILA

Dos., johtava ylihoitaja

HUS, Hoitotieteen tutkimuskeskus (NRC)

ja Helsingin yliopisto

TONI HAAPA

TtT, tutkimusylihoitaja

HUS, Hoitotieteen tutkimuskeskus (NRC) ja Helsingin yliopisto

TANJa LaukKala

Dos. vs.osastonylilääkäri

HUS Psykiatria ja Helsingin yliopisto 